Administração Pública e 4,8\% em Organizações de Solidariedade Social. Quanto ao currículo transitório, 79,6\% estagiaram em Empresas, 11,1\% em Autarquias Locais, 5,6\% em Associações e 3,8\% na Administração Pública e Organizações de Solidariedade Social.

Os estágios curriculares, realizados no ano lectivo de 1996/97 decorreram, na sua maioria, em empresas industriais, comerciais e de serviços localizadas, predominantemente, no Distrito de Viseu.

A experiência colhida no ano lectivo de 1996/97, nomeadamente através da introdução das duas tipologias de estágio, suscita-nos as seguintes reflexões:

- quer por parte das organizações acolhedoras, quer ao nível da produção do relatório final, a redução do período de estágio para quatro meses não favorece os objectivos propostos para o mesmo;

- a crescente exigência, por parte das organizações acolhedoras, para a realização de processos de selecção próprios, deverá encontrar o enquadramento adequado no Regulamento de Estágio da Licenciatura em Gestão e Desenvolvimento Social.

Paulo Ribeiro

\title{
PROVAS DE MESTRADO DE DOCENTES DO IUDPS
}

Alcançaram o grau de mestre, com aprovação final de MUITO BOM, dois licenciados do IUDPS, Maria da Graça Ferreira e Paulo Alexandre de Oliveira Castro Ribeiro.

A Dra. Maria da Graça Ferreira, recentemente falecida e grande perda para o nosso Instituto, era assistente da área de Recursos Humanos. Defendeu, em 16 de Julho de 1996, a sua dissertação de Mestrado em Políticas e Gestão de Recursos Humanos, no Instituto Superior de Ciências do Trabalho e da Empresa, com o tema Modernização Empresarial e a Renovação dos Perfis Profissionais - O Sector Têxtil no Vale do Ave, sob orientação da Prof. a Doutora Maria João Rodrigues.

O Dr. Paulo Alexandre de Oliveira Castro Ribeiro, assistente da área de Gestão e Informática, defendeu, em 13 de Fevereiro de 1997, a sua tese de Mestrado na especialidade de Gestão Estratégia e Desenvolvimento Empresarial, no Instituto Superior de Ciências do Trabalho e da Empresa, com o tema Estudo de Mercado - Turismo no Espaço Rural na Região Turística das Montanhas, sob a orientação da Prof. ${ }^{a}$ Doutora Elisabeth Reis. 